\title{
Pre-industrial and mid-Pliocene simulations with NorESM-L
}

\author{
Z. S. Zhang ${ }^{1,2,3}$, K. Nisancioglu ${ }^{1,2}$, M. Bentsen ${ }^{1,2}$, J. Tjiputra ${ }^{1,2}$, I. Bethke ${ }^{1,2}$, Q. Yan $^{3}$, B. Risebrobakken ${ }^{1,2}$, \\ C. Andersson ${ }^{1,2}$, and E. Jansen ${ }^{1,2}$ \\ ${ }^{1}$ Bjerknes Centre for Climate Research, Allegaten 55, 5007, Bergen, Norway \\ ${ }^{2}$ UNI Research, Allegaten 55, 5007, Bergen, Norway \\ ${ }^{3}$ Nansen-Zhu International Research Center, Institute of Atmospheric Physics, Chinese Academy of Sciences, \\ 100029, Beijing, China
}

Correspondence to: Z. S. Zhang (zhongshi.zhang@bjerknes.uib.no)

Received: 20 December 2011 - Published in Geosci. Model Dev. Discuss.: 13 January 2012

Revised: 3 April 2012 - Accepted: 3 April 2012 - Published: 25 April 2012

\begin{abstract}
The mid-Pliocene period (3.3 to $3.0 \mathrm{Ma}$ ) is known as a warm climate with atmospheric greenhouse gas levels similar to the present. As the climate at this time was in equilibrium with the greenhouse forcing, it is a valuable test case to better understand the long-term response to high levels of atmospheric greenhouse gases. In this study, we use the low resolution version of the Norwegian Earth System Model (NorESM-L) to simulate the pre-industrial and the mid-Pliocene climate. Comparison of the simulation with observations demonstrates that NorESM-L simulates a realistic pre-industrial climate. The simulated mid-Pliocene global mean surface air temperature is $16.7^{\circ} \mathrm{C}$, which is $3.2^{\circ} \mathrm{C}$ warmer than the pre-industrial. The simulated midPliocene global mean sea surface temperature is $19.1^{\circ} \mathrm{C}$, which is $2.0^{\circ} \mathrm{C}$ warmer than the pre-industrial. The warming is relatively uniform globally, except for a strong amplification at high latitudes.
\end{abstract}

\section{Introduction}

The mid-Pliocene period, also referred to as the midPiacenzian, is known as the most recent period in Earth's history when the global average temperature was warmer than today. Estimates are on the order of $2-3{ }^{\circ} \mathrm{C}$ warmer compared to today (Jansen et al., 2007; Dowsett et al., 2010). This warming is accompanied by a global sea level that was $10-45 \mathrm{~m}$ higher than present (e.g. Raymo et al., 1996). The warming is within the range of the Intergovernmental Panel on Climate Change (IPCC) projections of global temperature increases for the 21 st century (Meehl et al., 2007). Unlike other warm geological periods, e.g. Eocene and Miocene, the paleogeography of the mid-Pliocene is similar to the present. Thus, the mid-Pliocene climate has been considered as an analog for the long-term fate of the climate system under the present level of greenhouse gases forcing.

The mid-Pliocene has been a focus for several data syntheses (e.g. Dowsett et al., 1994, 1996, 1999, 2009, 2010) and modelling (e.g. Chandler et al., 1994; Sloan et al., 1996; Haywood et al., 2000; Haywood and Valdes, 2004; Jiang et al., 2005; Yan et al., 2011). However, early model studies indicated a clear model-data discrepancy. Interpretation of the proxy data suggested that the Atlantic Meridional Overturning Circulation (AMOC) was stronger in the mid-Pliocene compared to the present (Raymo et al., 1996; Ravelo and Andreasen, 2000; Hodell and Venz-Curtis, 2006). The enhanced AMOC was thought to have led to increased northward heat transport and warm temperatures in the high latitude Atlantic and Arctic (Dowsett et al., 1992, 2009). However, most climate models forced with mid-Pliocene boundary conditions did not simulate a stronger AMOC and enhanced heat transport (e.g. Haywood and Valdes, 2004; Yan et al., 2011). Thus, to better understand the dynamics behind the estimated high latitude warmth of the mid-Pliocene, and to assess the ability of climate models in simulating a past warm climate, the Pliocene Paleoclimate Modeling Intercomparison Project (PlioMIP) was recently initiated (Haywood et al., 2010, 2011).

The pre-industrial and mid-Pliocene experiments with the low resolution version of the Norwegian Earth System Model (NorESM-L) presented in this paper are a contribution from the Bjerknes Centre for Climate Research and the Norwegian 
Climate Centre (NCC) to the PlioMIP experiment II. The NorESM-L model is introduced in detail in Sect. 2. Section 3 describes the experimental design and Sect. 4 discusses the results. A brief discussion and summary are given in Sect. 5 .

\section{Model description}

The NorESM is an Earth system model built under the structure of the Community Earth System Model (CESM) from the National Center for Atmospheric Research (NCAR). It uses the same coupler (CLP7), atmosphere (CAM4), land (CLM4), and sea ice (CICE4) components as the CESM. The key difference to the standard CESM configuration is an optional modification of the treatment of atmospheric chemistry, aerosols, and clouds (Seland et al., 2008) and the ocean component, which is the Miami Isopycnic Coordinate Ocean Model (MICOM) in the NorESM. Simulations with the NorESM are the contributions from the Norwegian Climate Centre (NCC) to the Coupled Model Intercomparison Project Phase 5 (CMIP5), which is expected to be included in the upcoming Intergovernmental Panel on Climate Change (IPCC) Fifth Assessment Report (AR5).

In this study we use the low resolution version of the NorESM (NorESM-L). The horizontal resolution for the atmosphere is T31, with 26 levels in the vertical. This corresponds roughly to a grid size of approximately $3.75^{\circ} \mathrm{C}$. The horizontal resolution of the ocean is $\mathrm{g} 37$, corresponding to a nominal grid size of $3{ }^{\circ} \mathrm{C}$. The ocean component has 30 isopycnic layers in the vertical. Detailed documentations for each component of the model system are given in the following sections.

\subsection{Atmospheric model}

The atmosphere component of the NorESM-L is the spectral Community Atmosphere Model CAM4 (Neale et al., 2010; Eaton, 2010). It uses the Eulerian dynamical core, which is based on the hybrid vertical coordinate developed by Simmons and Strüfing (1981). The model includes physical parameterizations of convection, clouds, surface processes, and turbulent mixing. The parameterization of deep convection uses the scheme developed by Zhang and McFarlane (1995), together with the convective momentum transport modification developed by Richter and Rasch (2008), and the dilute plume modification developed by Raymond and Blyth (1986, 1992). The parameterization of clouds uses the scheme introduced by Slingo (1987), with the variations described by Hack et al. (1993), Kiehl et al. (1998), and Rasch and Kristjánsson (1998). The parameterization of surface processes uses a bulk exchange formulation described by Neale et al. (2010) to calculate the surface exchange of heat, moisture and momentum between the atmosphere and land, ocean or ice surfaces. The parameterization of turbulence includes the scheme of free atmosphere turbulent diffusivities and the scheme of non-local atmospheric boundary layer parameterization described by Holtslag and Boville (1993) and Neale et al. (2010). The standard CAM4 treatment of atmospheric chemistry, aerosols, and clouds is used in this study. Detailed introductions to CAM4 can be found in the scientific description of CAM4 (Neale et al., 2010) and the user guide (Eaton, 2010).

\subsection{Land model}

The land component used in NorESM-L is the Community Land Model CLM4 (Oleson et al., 2010; Kluzek, 2011). It calculates radiation and heat fluxes at the land-atmosphere interface, as well as temperature, humidity, and soil thermal and hydrologic states. The sub-grid scale surface heterogeneity is represented through fractional coverage of glacier, lake, wetland, urban, and vegetation consisting of up to 15 plant functional types (PFTs) plus bare ground. Soil colours in the model are fitted to a range of 20 soil classes. The radiation fluxes are calculated according to the formulation introduced by Oleson et al. (2010). The heat fluxes are calculated using the Monin-Obukhov similarity theory as described by Zeng et al. (1998). Soil and snow temperatures are calculated according to the numerical solution introduced by Oleson et al. (2010). The model calculates changes in canopy water, snow water, soil water, and soil ice and water. A river transport model is included to give a closed hydrological cycle. Detailed descriptions of CLM4 can be found in the technical description (Oleson et al., 2010) and the user guide (Kluzek, 2011).

\subsection{Sea ice model}

The sea ice component used in NorESM-L is the Community Ice CodE CICE4 (Bailey et al., 2010; Hunke and Lipscomb, 2010). In the CICE model, the evolution of ice thickness distribution is controlled by the three types of sea ice transport, including transport in horizontal space following an incremental remapping scheme (Dukowicz and Baumgardner, 2000; Lipscomb and Hunke, 2004), transport in thickness space due to thermodynamic growth following the Lipscomb remapping scheme (Lipscomb, 2001), and the melting and redistribution of ice in thickness space due to ridging and other mechanical processes (Thorndike et al., 1975; Rothrock, 1975; Hibler, 1980; Flato and Hibler, 1995; Lipscomb et al., 2007). Elastic-viscous-plastic ice dynamics (Hunke and Dukowicz, 1997) are used to calculate velocity. The Bitz-Lipscomb thermodynamic model (Bitz and Lipscomb, 1999) is employed to compute ice growth rate. Detailed introductions to CICE can be found in the CICE documentation and user manual (Hunke and Lipscomb, 2010) and the user guide (Bailey et al., 2010). 
Table 1. Boundary and initial conditions for the pre-industrial and the mid-Pliocene experiment.

\begin{tabular}{lll}
\hline Conditions & Pre-Industrial & Mid-Pliocene \\
\hline Ocean model & & \\
\hline $\begin{array}{l}\text { Land-sea mask/Bathymetry } \\
\text { Initialization }\end{array}$ & $\begin{array}{l}\text { Local modern } \\
\text { Levitus T/S }\end{array}$ & $\begin{array}{l}\text { Local modern } \\
\text { Levitus T/S }\end{array}$ \\
\hline Atmosphere model & & \\
\hline Topography & Local modern & Anomalies + local modern \\
$\mathrm{CO}_{2}$ & $280 \mathrm{ppm}$ & $405 \mathrm{ppm}$ \\
$\mathrm{N}_{2} \mathrm{O}$ & $270 \mathrm{ppb}$ & $270 \mathrm{ppb}$ \\
$\mathrm{CH}_{4}$ & $760 \mathrm{ppb}$ & $760 \mathrm{ppb}$ \\
$\mathrm{CFCs}$ & 0 & 0 \\
Solar constant & $1370 \mathrm{~W} \mathrm{~m}{ }^{-2}$ & $1370 \mathrm{~W} \mathrm{~m} \mathrm{~m}^{-2}$ \\
\hline Land model & & \\
\hline Vegetation & Local pre-industrial & PRISM vegetation \\
\hline Coupler & & \\
\hline Orbital parameters & Year 1950 & Year 1950 \\
\hline
\end{tabular}

\subsection{Ocean model}

The ocean component used in the NorESM-L is based on the Miami Isopycnic Coordinate Ocean Model MICOM (Bleck and Smith, 1990; Bleck et al., 1992), which uses potential density as vertical coordinate. The model consists of a stack of 30 isopycnal layers evaluated against a reference pressure of $2000 \mathrm{db}$, and a mixed layer on top represented by two nonisopycnal layers, providing the linkage between the atmospheric forcing and the ocean interior. Modifications of the original MICOM have been prompted by the desire to improve conservation of mass, heat, and tracers and to implement robust, accurate, and efficient transport of many tracers, which is particularly important for ocean biogeochemistry modelling. Furthermore, the pressure gradient force is now accurately estimated using in situ density, the diapycnal diffusion equation is solved by an implicit method, and numerous physical parameterizations have been improved or added in order to reduce model biases particular in coupled climate model configurations. These changes are described by Assmann et al. (2010) and Alterskjær et al. (2012).

\section{Experimental designs}

\subsection{Pre-industrial control experiment}

Following the PlioMIP experimental guidelines (Haywood, et al., 2011), the pre-industrial control experiment presented in this paper uses the modern land-sea mask, topography, and the ice sheets and vegetation for year 1850 (Table 1). All these geographic boundary conditions are taken from the CESM (Vertenstein et al., 2010). The ocean model uses the modern bathymetry and is initialized from Levitus temperature and salinity (Levitus and Boyer, 1994). Atmospheric greenhouse gases are set to the pre-industrial values of $280 \mathrm{ppm} \mathrm{CO}_{2}, 270 \mathrm{ppb} \mathrm{N}_{2} \mathrm{O}, 760 \mathrm{ppb} \mathrm{CH}_{4}$, and zero levels of CFCs. The solar constant is set to $1370 \mathrm{~W} \mathrm{~m}^{-2}$. Orbital parameters are set to the values for 1950 (Berger, 1978). The pre-industrial aerosol conditions from the CESM (Vertenstein et al., 2010) are used in the pre-industrial control experiment. With these boundary conditions and initial conditions, the pre-industrial control experiment is run for $1500 \mathrm{yr}$.

\subsection{Mid-Pliocene experiment}

In the mid-Pliocene experiment (Table 1), the conditions for the ocean model are set following the PlioMIP experiment guidelines (Haywood, et al., 2011). However, the land-sea mask is not changed in the mid-Pliocene experiment. The ocean model (MICOM) used in the NorESM-L uses an irregular and complicated 3-D grid system (dipole grids in horizontal and isopycnic layers in vertical). With this grid system, a new latitude and longitude grid system has to be rebuilt, if a new land-sea mask is used. Then, mapping weights between the atmosphere model and the ocean model have to be recreated. If the mapping weights are changed, land fractions, runoff and some other boundary conditions have to be reset. These large changes potentially bring some uncertainties in simulating the mid-Pliocene climate. In order to avoid these uncertainties, the identical land-sea mask and bathymetry to the pre-industrial experiment are used in the mid-Pliocene experiment. In the land-sea mask, the Central American Seaway (Panama Gateway) is kept closed, and the Bering Strait, Madagascar Strait, Drake Passage, Tasman Gateway, Gibraltar Strait and Indonesian Gateway are kept 


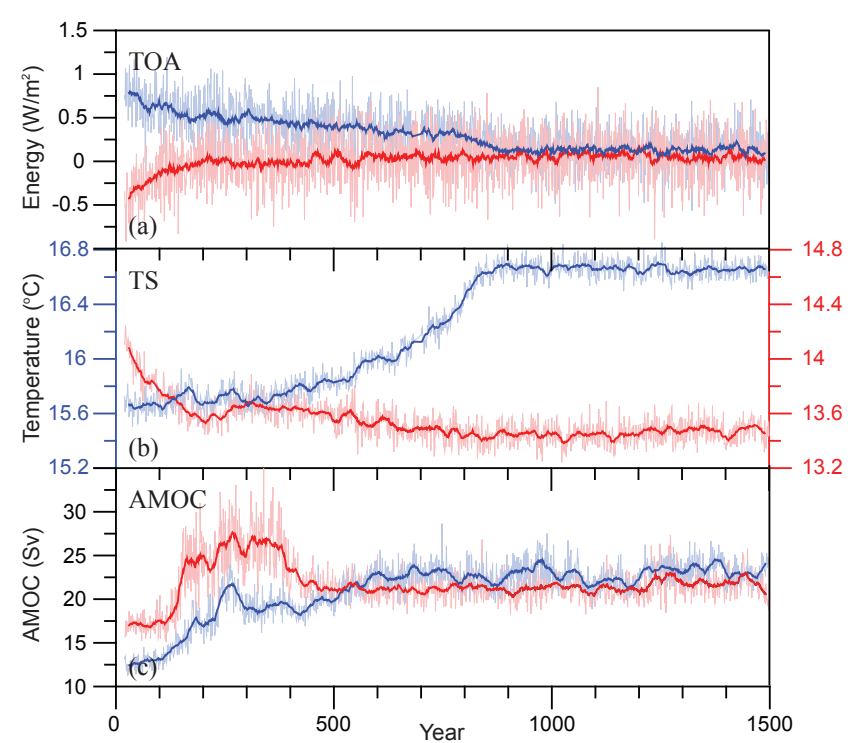

Fig. 1. Time series for (a) the energy balance at the top of NorESM$\mathrm{L}\left(\mathrm{W} \mathrm{m}^{-2}\right)$, (b) surface temperature $\left({ }^{\circ} \mathrm{C}\right)$, and (c) the maximum of the Atlantic overturning stream function $(\mathrm{Sv})$ in the pre-industrial (red) and the mid-Pliocene experiment (blue). The thin lines show annual mean values and the bold lines show 21-yr running averages.

opened. Furthermore, the PRISM DOT deep ocean temperature (Dowsett et al., 2009) is not used to initialize the ocean model in the mid-Pliocene experiment. Due to the complexity in the grid system, the initial depth of each isopycnic layer has to be reestimated, if the initial temperature and salinity are changed. These changes largely modify the initial ocean stratification. In order to avoid the large modifications in the initial ocean stratification, the initial conditions, which are identical to the pre-industrial experiment, are used in the preindustrial experiment.

The PRISM Pliocene topography file topo_v1.3 (Sohl et al., 2009) is used to build the topography for the experiment. The difference between PRISM Pliocene topography and PRISM modern topography is interpolated to the T31 resolution. Then, the interpolated difference is added to the modern topography used in the pre-industrial experiment.

The PRISM Pliocene vegetation biome_veg_v1.2 (Hill et al., 2007; Salzmann et al., 2008) is used to construct the vegetation and ice sheets for the mid-Pliocene experiment. The PRISM Pliocene vegetation is interpolated to the T31 resolution. Subsequently, the biome vegetation types are changed to the LSM (Land System Model) vegetation types, according to the table named Biome 4 conversion to LSM edited by Rosenbloom (2009). Finally, the LSM vegetation file is converted to appropriate boundary conditions for the CLM using the CCSM paleoclimate tools from NCAR (Rosenbloom et al., 2010).
Table 2. Global mean value for the pre-industrial and the midPliocene experiment.

\begin{tabular}{lll}
\hline Exp. & Pre-industrial & Mid-Pliocene \\
\hline Top energy balance & $0.04 \mathrm{~W} \mathrm{~m}^{-2}$ & $0.13 \mathrm{~W} \mathrm{~m}^{-2}$ \\
Surface temperature & $13.5^{\circ} \mathrm{C}$ & $16.7^{\circ} \mathrm{C}$ \\
Precipitation & $2.7 \mathrm{~mm} \mathrm{~d}^{-1}$ & $2.9 \mathrm{~mm} \mathrm{~d}^{-1}$ \\
Sea surface temperature & $17.1^{\circ} \mathrm{C}$ & $19.1^{\circ} \mathrm{C}$ \\
Maximum AMOC & $21.8 \mathrm{~Sv}$ & $23.4 \mathrm{~Sv}$ \\
\hline
\end{tabular}

For the greenhouse gases, the atmospheric $\mathrm{CO}_{2}$ level is set to $405 \mathrm{ppm}$. Other greenhouse gases are kept at the same levels as those in the pre-industrial control experiment. Other boundary conditions, including solar constant, orbital parameters and aerosols, are also kept at the same levels as the preindustrial control experiment.

\subsection{Time integration}

The pre-industrial and mid-Pliocene experiments are both run for $1500 \mathrm{yr}$. Time series of the top of the atmosphere energy balance, global mean surface air temperature and maximum Atlantic meridional overturning circulation (AMOC) are shown in Fig. 1. Both experiments reach an equilibrium state after approximately $1000 \mathrm{yr}$ of model integration time. In this paper we calculate the climatological means from the last $200 \mathrm{yr}$ of each simulation.

\section{Results}

\subsection{Pre-industrial control experiment}

\subsubsection{Surface air temperature}

For the pre-industrial experiment, the global annual mean surface air temperature (SAT) is $13.5^{\circ} \mathrm{C}$ (Table 2, Fig. 1), in good agreement with pre-industrial temperature estimates (e.g. Hansen et al., 2010). The zonal mean SAT (Fig. 2a) shows that the annual mean temperature at the North Pole is about $-20^{\circ} \mathrm{C}$, whereas it is $-44^{\circ} \mathrm{C}$ close to the South Pole. The warmest temperatures are found over the western tropical Pacific and eastern tropical Indian Ocean, with temperatures higher than $28^{\circ} \mathrm{C}$ (Fig. 3a). The coldest temperatures are found over East Antarctica, with temperatures below $-50^{\circ} \mathrm{C}$. The zero degree isotherm in the Southern Hemisphere is relatively zonal and located close to $60^{\circ} \mathrm{S}$. In contrast, the zero degree isotherm in the Northern Hemisphere is strongly influenced by topography and land-sea distribution. It is located close to $70^{\circ} \mathrm{N}$ over the Labrador Sea and the Norwegian Sea, and close to $60^{\circ} \mathrm{N}$ in the North Pacific.

The simulated pre-industrial SAT is in good agreement with the ERA-interim (Dee et al., 2011) temperature data (Fig. 3b). However, as expected, the simulated pre-industrial 

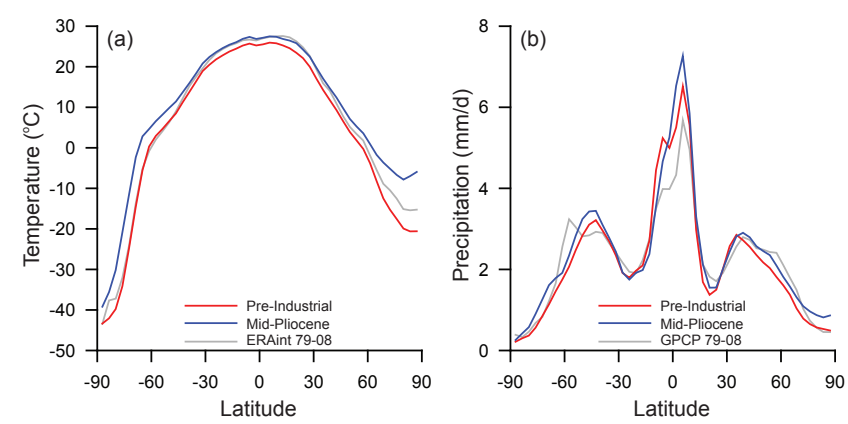

Fig. 2. Zonal mean surface temperature $\left(\mathbf{a},{ }^{\circ} \mathrm{C}\right)$ and precipitation $\left(\mathbf{b}, \mathrm{mm} \mathrm{d}^{-1}\right)$ for the observations (gray lines), the preindustrial experiment (red lines) and the mid-Pliocene experiment (blue lines). The temperature observation is ERA-interim temperature from 1979 to 2008 . The precipitation observation is the 1979-2008 precipitation from the Global Precipitation Climatology Project (GPCP).

temperatures are slightly colder than the modern estimates represented by the ERA-interim data.

\subsubsection{Precipitation}

In the pre-industrial experiment, the global annual mean precipitation is $2.7 \mathrm{~mm} \mathrm{day}^{-1}$ (Table 2), with a peak in annual zonal mean precipitation in the Intertropical Convergence Zone (ITCZ) of about $6.5 \mathrm{~mm} \mathrm{day}^{-1}$ (Fig. 2b). The lowest precipitation, about $0.2 \mathrm{~mm} \mathrm{day}^{-1}$, appears close to the South Pole. Regionally (Fig. 3c), high precipitation can be seen over the tropical ocean and continent, with annual mean precipitation higher than $12 \mathrm{~mm}_{\text {day }}{ }^{-1}$ over the western tropical Pacific. In the Sahara and over East Antarctica, precipitation is less than $0.2 \mathrm{~mm} \mathrm{day}^{-1}$.

Compared to the observed precipitation data from the Global Precipitation Climatology Project (GPCP; Adler et al., 2003) averaged over the period 1979-2008 (Fig. 3d), the overall pattern and amount are in good agreement. However, model-data discrepancies exist in the tropics and in the Southern Hemisphere sub-tropical oceans, where the simulated precipitation is higher than the observations.

\subsubsection{Sea surface temperature}

In the pre-industrial experiment, the global annual mean SST is $17.1^{\circ} \mathrm{C}$ (Table 2), with the warmest temperatures, higher than $28^{\circ} \mathrm{C}$, in the western tropical Pacific and eastern tropical Indian Ocean (Fig. 4a). The zero degree isotherm is located close to $60^{\circ} \mathrm{S}$ in the Southern Hemisphere and around the margin of the Arctic in the Northern Hemisphere.

The simulated SSTs compare well with the data of Levitus and Boyer (1994, Fig. 4b). However, the model simulations are slightly cooler than the observations, in particular in the tropical oceans. This is expected, as the observations represent today's SST and not pre-industrial values.

\subsubsection{Sea surface salinity}

High sea surface salinity occurs generally at the surface of the subtropical oceans (Fig. 4c). Salinity is relatively low at the surface of the tropical and high latitude oceans. The highest salinities, close to $38 \mathrm{~g} \mathrm{~kg}^{-1}$, appear at the surface of the Mediterranean Sea. The lowest salinities, with salinity less than $32 \mathrm{~g} \mathrm{~kg}^{-1}$, occur at the surface of marginal seas in the Arctic, the Hudson Bay (northeastern North America), the Gulf of Guinea (eastern tropical Atlantic) and the Indonesian archipelago (western tropical Pacific).

The global sea surface pattern (Fig. 4d) agrees well with observations (Levitus and Boyer, 1994). However, simulated salinities are a little lower than observed values at the surface of the Atlantic Ocean, but higher in the Arctic and the North Pacific.

\subsection{Mid-Pliocene experiment}

\subsubsection{Surface air temperature}

In the mid-Pliocene experiment, the global annual mean SAT is $16.7^{\circ} \mathrm{C}$ (Table 2, Fig. 1). The zonal mean annual SAT shows that the annual mean temperature close to the South Pole is about $-40^{\circ} \mathrm{C}$, whereas it is about $-7^{\circ} \mathrm{C}$ close to the North Pole (Fig. 2a). The annual mean temperature is about $27^{\circ} \mathrm{C}$ at the equator.

Compared to the pre-industrial control run, the simulated mid-Pliocene global annual mean SAT is $3.2^{\circ} \mathrm{C}$ warmer. Warming occurs almost globally (Fig. 5a), with stronger warming appearing in high latitudes. Cooler temperatures are simulated over parts of the western tropical Pacific, the Southern Ocean close to West Antarctica, tropical Africa, East Australia, and East Antarctica.

The warming can also be seen in the seasonal SAT anomalies between the mid-Pliocene and the pre-industrial. In boreal summer (Fig. 5b), the warming exceeds $5^{\circ} \mathrm{C}$ over Greenland in the Northern Hemisphere and around the margin of Antarctica in the Southern Hemisphere. In boreal winter (Fig. 5c), the middle and high latitude continents are significantly warmer in the Northern Hemisphere, with a temperature increase during the mid-Pliocene of more than $5^{\circ} \mathrm{C}$. The warming increases northward towards the North Pole, where temperatures increase as much as $20^{\circ} \mathrm{C}$. In the Southern Hemisphere, the strongest warming occurs around the Antarctic margin, with temperatures increasing more than $5^{\circ} \mathrm{C}$.

\subsubsection{Precipitation}

In the mid-Pliocene experiment, the global annual mean precipitation is $2.9 \mathrm{~mm} \mathrm{day}^{-1}$. The zonal mean annual precipitation shows that most precipitation appears near the equator, with about $7.3 \mathrm{~mm} \mathrm{day}^{-1}$ (Fig. 2b). The least precipitation, about $0.2 \mathrm{~mm} \mathrm{day}^{-1}$, appears close to the South Pole. 

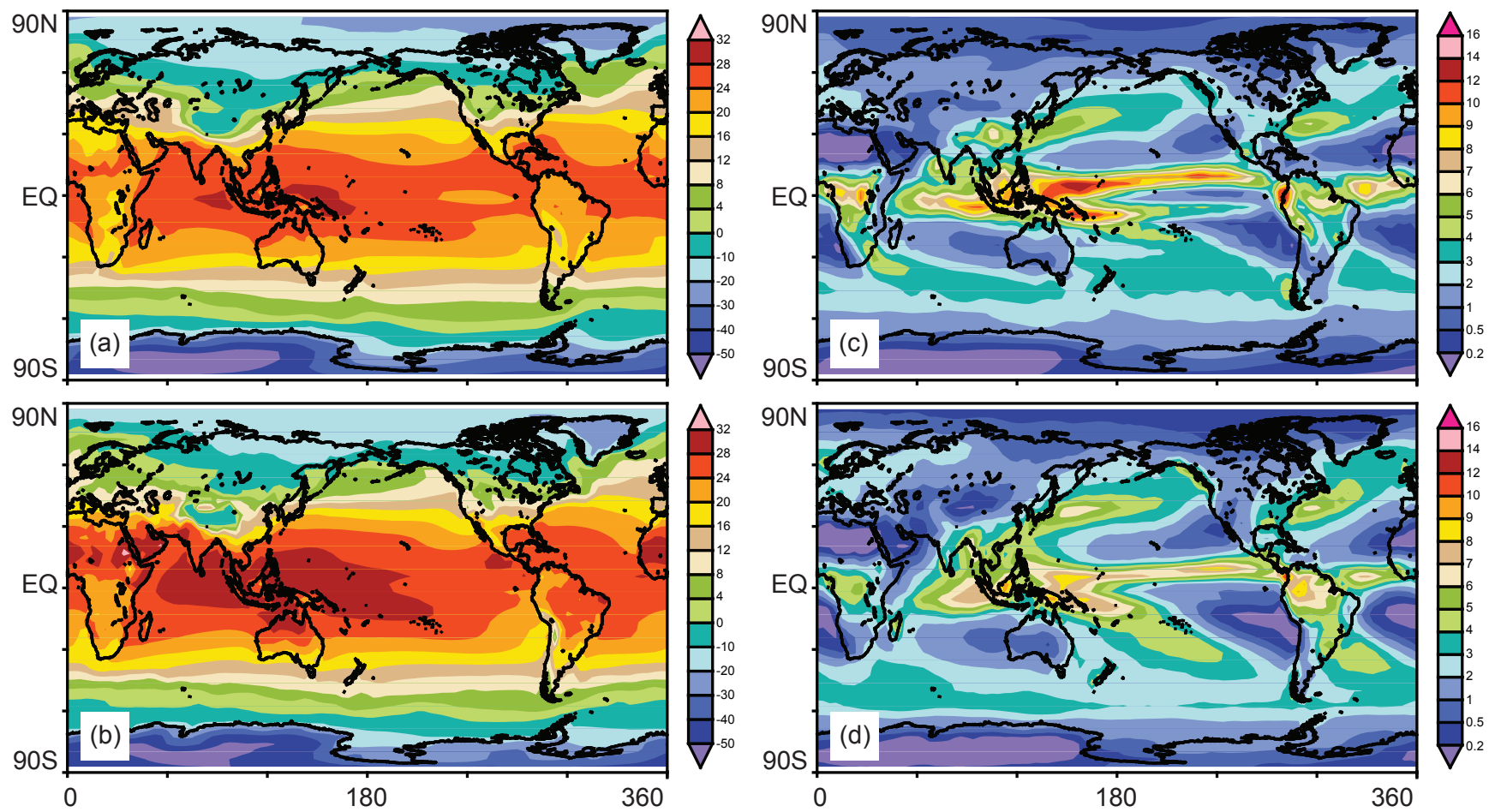

Fig. 3. Simulated annual mean pre-industrial surface temperature $\left(\mathbf{a},{ }^{\circ} \mathrm{C}\right)$ and precipitation $\left(\mathbf{c}, \mathrm{mm} \mathrm{d}^{-1}\right)$, in comparison to ERA-interim 1979-2008 surface temperature $\left(\mathbf{b},{ }^{\circ} \mathrm{C}\right)$ and GPCP 1979-2008 precipitation $\left(\mathbf{d}, \mathrm{mm} \mathrm{d}^{-1}\right)$.
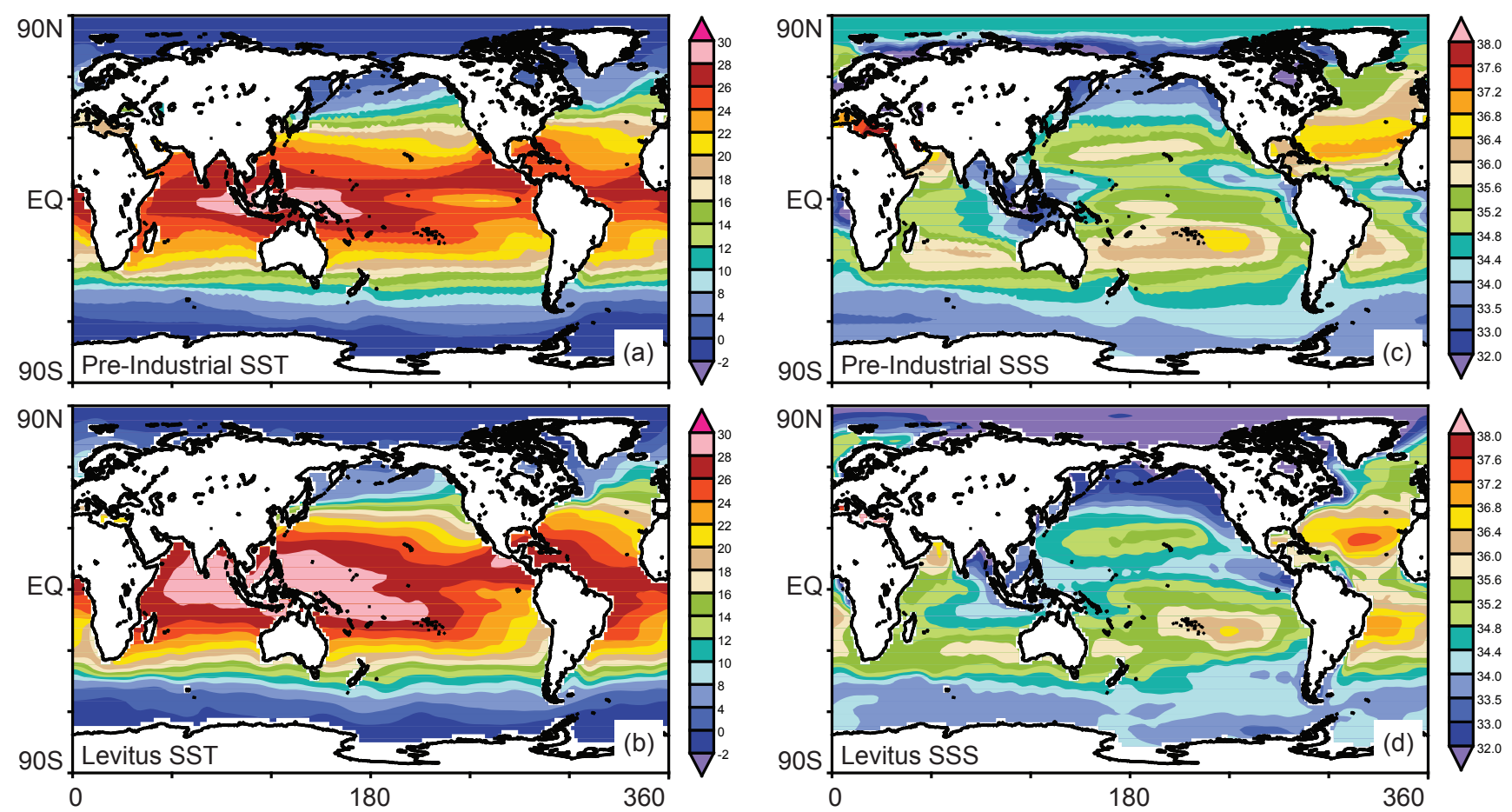

Fig. 4. Simulated annual mean pre-industrial sea surface temperature $\left(\mathbf{a},{ }^{\circ} \mathrm{C}\right)$ and salinity $\left(\mathbf{c}, \mathrm{g} \mathrm{kg}^{-1}\right)$, in comparison to LEVITUS94 sea surface temperature $\left(\mathbf{b},{ }^{\circ} \mathrm{C}\right)$ and salinity $(\mathbf{d}, \mathrm{psu})$. 

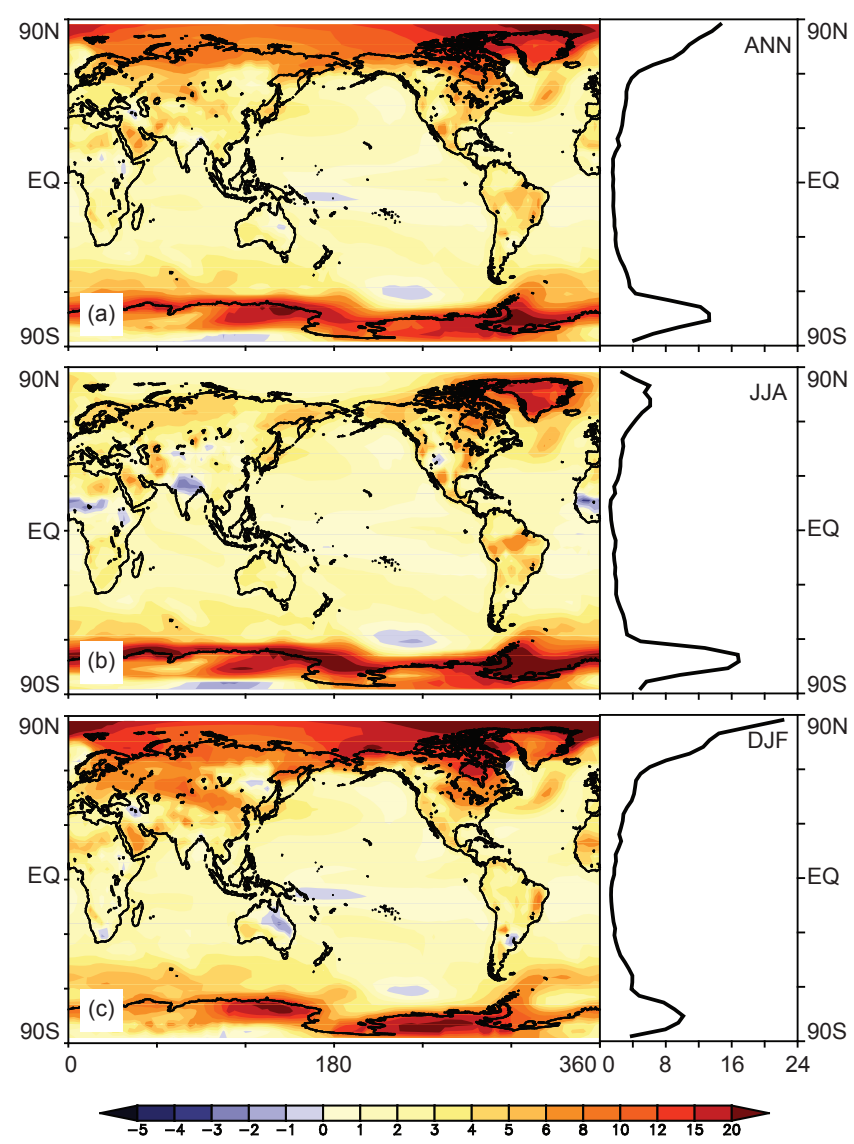

Fig. 5. Temperature differences $\left({ }^{\circ} \mathrm{C}\right)$ between the mid-Pliocene and the pre-industrial experiment, (a) for annual mean, (b) for boreal summer and (c) for boreal winter. The bold lines on the right sides show zonal mean values.

Compared to the pre-industrial experiment, the simulated mid-Pliocene global annual mean precipitation increases by about $0.2 \mathrm{~mm} \mathrm{day}^{-1}$. Precipitation increases in the tropics north of the equator by $1 \mathrm{~mm} \mathrm{day}^{-1}$, and in the middle and high latitudes of both hemispheres by $0.5 \mathrm{~mm} \mathrm{day}^{-1}$. Precipitation decreases in the subtropics of the Northern Hemisphere by $0.1 \mathrm{~mm} \mathrm{day}^{-1}$, and tropics of the Southern Hemisphere (Fig. 6a) by $0.9 \mathrm{~mm} \mathrm{day}^{-1}$. The differences similar to those of the zonal mean annual precipitation are also simulated in the seasonal precipitation anomalies (Fig. $6 \mathrm{~b}$ and c).

\subsubsection{Sea surface temperature}

In the mid-Pliocene experiment (Fig. 7a), the warmest ocean surfaces with temperature higher than $28^{\circ} \mathrm{C}$ appear in the tropical Indian Ocean, the western tropical Pacific, the eastern tropical Pacific and the eastern tropical Atlantic. The zero degree isotherm almost disappears in the Southern Hemisphere. In the Northern Hemisphere, it is located further
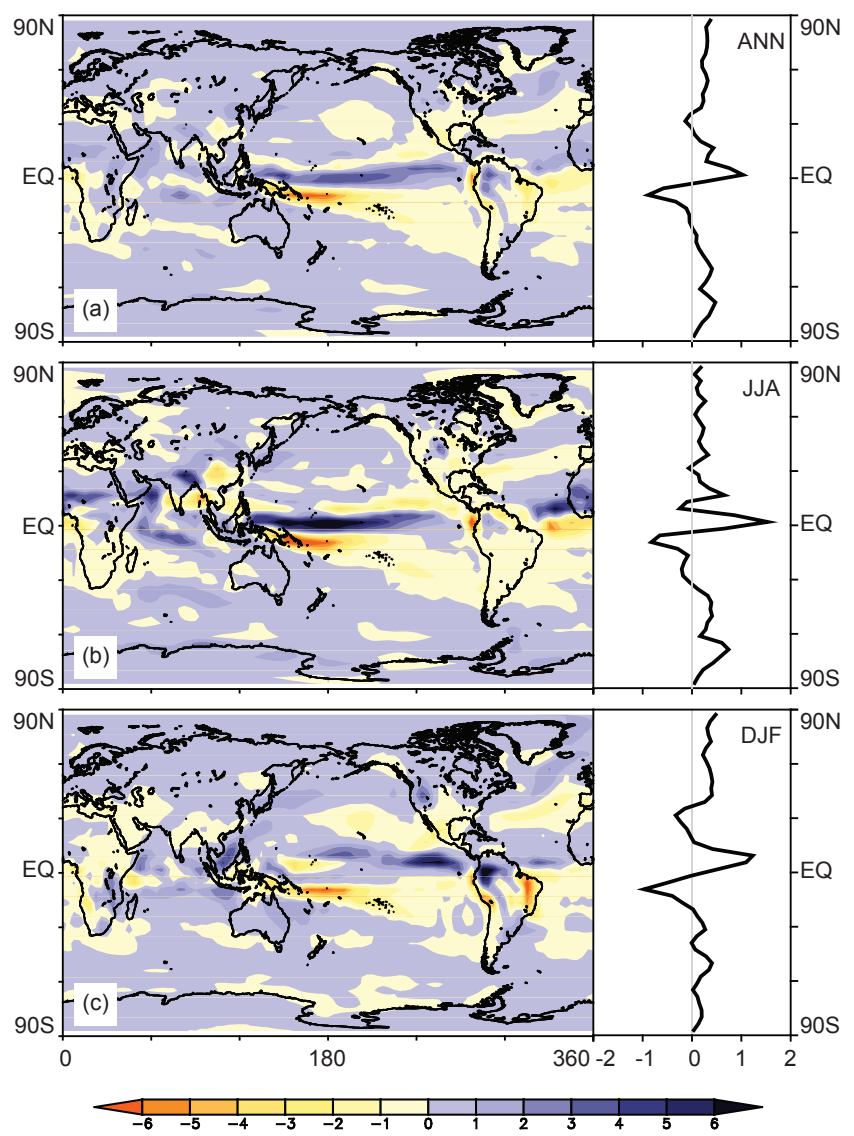

Fig. 6. Precipitation differences $\left(\mathrm{mm} \mathrm{d}^{-1}\right)$ between the midPliocene and the pre-industrial experiment, (a) for annual mean, (b) for boreal summer and (c) for boreal winter. The bold lines on the right sides show zonal mean values.

north than in the pre-industrial, and at about $75^{\circ} \mathrm{N}$ in the Arctic Ocean.

Compared to the pre-industrial SST, almost the entire ocean surface is warmer in the mid-Pliocene experiment (Fig. 7b). The strongest warming, with SST increased by more than $3{ }^{\circ} \mathrm{C}$, occurs at the surface of the Greenland Sea, the central North Atlantic, the Japanese Sea and the Southern Ocean off East Antarctica. There are only a few small regions where temperatures decrease (by less than $1{ }^{\circ} \mathrm{C}$ ) in the midPliocene relative to the pre-industrial experiment. These regions can be found in the Norwegian Sea, the Labrador Sea, the western tropical Pacific, and the Southern Ocean off the coast of West Antarctica.

\subsubsection{Sea surface salinity}

The basic pattern of mid-Pliocene SSS is similar to the pre-industrial (Fig. 7c). However, the mid-Pliocene salinity decreases at the surface of the Arctic and the Indian Ocean relative to the pre-industrial by $2 \mathrm{~g} \mathrm{~kg}^{-1}$ (Fig. 7d), but increases at the surface of the Atlantic, the Pacific, 

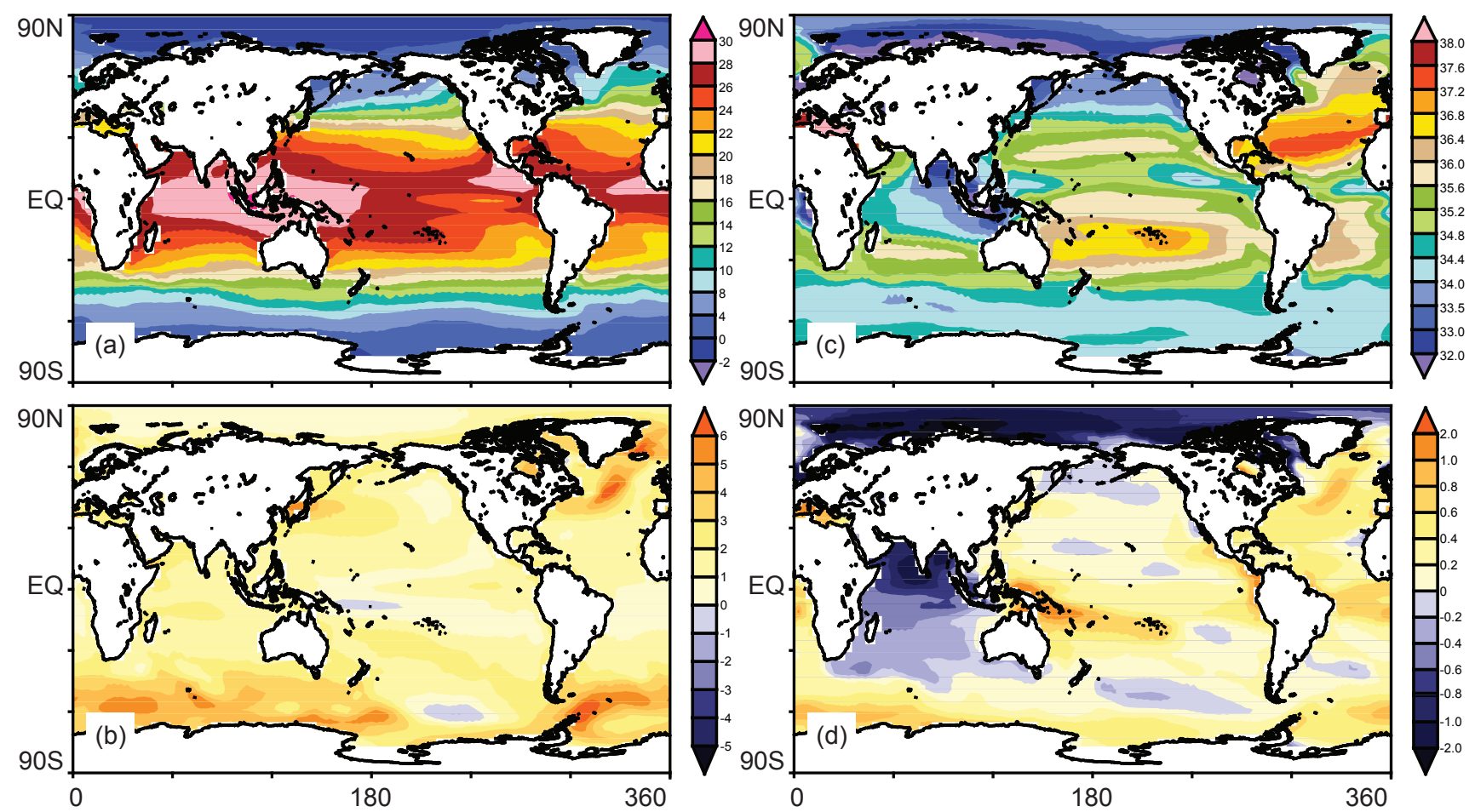

Fig. 7. Simulated mid-Pliocene SST $\left(\mathbf{a},{ }^{\circ} \mathrm{C}\right)$ and SSS $\left(\mathbf{c}, \mathrm{g} \mathrm{kg}^{-1}\right)$, and SST $\left(\mathbf{b},{ }^{\circ} \mathrm{C}\right)$ and SSS $\left(\mathbf{d}, \mathrm{g} \mathrm{kg}^{-1}\right)$ differences between the mid-Pliocene and the pre-industrial experiment.

and the Southern Ocean by $1 \mathrm{~g} \mathrm{~kg}^{-1}$. Large SSS increases $\left(\Delta S S S>0.6 \mathrm{~g} \mathrm{~kg}^{-1}\right)$ appear in the central North Atlantic, the Mediterranean Sea, the western tropical Pacific, the western coast of Central America, the tropical Atlantic, and the Southern Ocean off East Antarctica.

\section{Discussion}

As described in the previous section, the NorESM-L preindustrial simulation is in good agreement with observations. The simulated mid-Pliocene climate is warmer, as expected due to the elevated atmospheric $\mathrm{CO}_{2}$ level. Most of this warming is concentrated at high latitudes, and is most pronounced in the Arctic during boreal winter. The simulated high latitude warmth is consistent with the PRISM sea surface temperature reconstructions (Dowsett et al., 2009, 2010), although the proxy set is very sparse in the Nordic Seas and Arctic.

In addition to the warming, cooling is also simulated in some small areas in the mid-Pliocene, relative to the preindustrial experiment. It seems that the changes in topography are the main reason for the cooling simulated on land. At ocean surface, the reason for the cooling is more complicated. Changes in ocean currents can be one of the reasons, for example in the Norwegian Sea. However, detailed investigations of these cooling areas remain interesting for future studies.
Earlier studies have pointed to an enhanced AMOC to account for reconstructions of relatively warm mid-Pliocene sea surface temperatures in the North Atlantic (Dowsett et al., 1992; Raymo et al., 1996; Ravelo et al., 2000; Hodell et al., 2006; Dowsett et al., 2009, 2010). However, in our study the simulated AMOC is similar to that of the pre-industrial, with a maximum overturning stream function only $1.6 \mathrm{~Sv}$ stronger in the mid-Pliocene. More importantly, the return flow of NADW occurs at a slightly shallower depth in the mid-Pliocene experiment (Fig. 8).

Although the AMOC is slightly stronger in the midPliocene experiment, the total northward heat transport by the Atlantic is reduced (not shown). Thus, the simulated warm surface temperatures at high latitudes of the North Atlantic cannot be attributed to changes in ocean overturning or ocean heat transport. A more likely candidate for the surface warming is the reduced size of the Greenland ice sheet (Lunt et al., 2009). Other possible mechanisms are (1) a reduction in sea ice, (2) increased poleward atmospheric heat transport, (3) strong near-surface atmospheric stability leading to a large, albeit shallow high-latitude temperature response and (4) enhanced downward long-wave radiation due to changes in atmospheric moisture and clouds. However, a detailed investigation of these mechanisms is beyond the scope of this paper, and will be pursued in a future publication. 


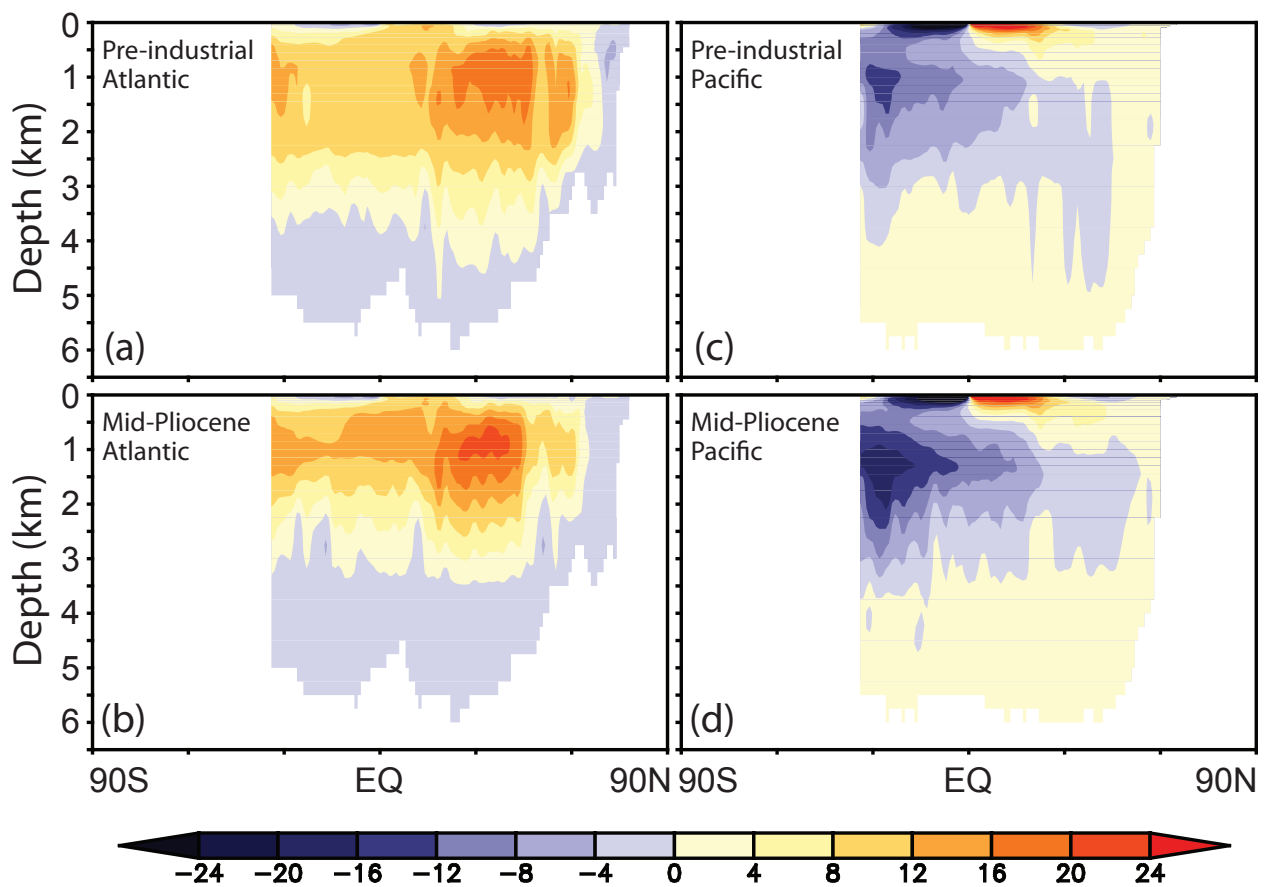

Fig. 8. Smoothed overturning stream function (Sv) (a) for pre-industrial Atlantic Basin, (b) for mid-Pliocene Atlantic Basin, (c) for preindustrial Pacific Basin and (d) for mid-Pliocene Pacific Basin.

\section{Summary}

In this paper, we describe pre-industrial and mid-Pliocene experiments simulated with the NorESM-L. Comparison of the simulation with observations demonstrates that the NorESM$\mathrm{L}$ simulates a realistic pre-industrial climate. Compared to the pre-industrial simulation, the global mid-Pliocene surface temperature is $3.2^{\circ} \mathrm{C}$ warmer. Warming occurs almost globally, with stronger warming occurring in the high latitudes. In the mid-Pliocene experiment, global annual mean precipitation increases by $0.2 \mathrm{~mm} \mathrm{day}^{-1}$.

At the ocean surface, the simulated mid-Pliocene global mean SST is $2.0^{\circ} \mathrm{C}$ warmer than the pre-industrial. More importantly, the warming exceeds $3^{\circ} \mathrm{C}$ at the surface of the Greenland Sea, in the central North Atlantic, and in the Southern Ocean off the coast of East Antarctica. Salinity increases at the surface of the Atlantic, the Pacific and the Southern Ocean by $1 \mathrm{~g} \mathrm{~kg}^{-1}$, but decreases at the surface of the Arctic and the Indian Oceans by $2 \mathrm{~g} \mathrm{~kg}^{-1}$.

Acknowledgements. This study was jointly supported by the Earth System Modeling (ESM) project financed by Statoil, Norway, the National 973 Program of China (Grant No. 2010CB950102), and the National Natural Science Foundation of China (Grant No. 40902054). The NorESM development was supported by the Integrated Earth System Approach to Explore Natural Variability and Climate Sensitivity (EARTHCLIM) project, which is a nationally coordinated climate research project in Norway.

Edited by: D. Lunt

\section{References}

Adler, R. F., Huffman, G. J., Chang, A., Ferraro, R., Xie, P., Janowiak, J., Rudolf, B., Schneider, U., Curtis, S., Bolvin, D., Gruber, A., Susskind, J., and Arkin, P.: The Version 2 Global Precipitation Climatology Project (GPCP) Monthly Precipitation Analysis (1979-Present), J. Hydrometeor., 4, 1147-1167, 2003.

Alterskjær, K., Kristjánsson, J. E., and Seland, Ø.: Sensitivity to deliberate sea salt seeding of marine clouds - observations and model simulations, Atmos. Chem. Phys., 12, 2795-2807, doi:10.5194/acp-12-2795-2012, 2012.

Assmann, K. M., Bentsen, M., Segschneider, J., and Heinze, C.: An isopycnic ocean carbon cycle model, Geosci. Model Dev., 3, 143-167, doi:10.5194/gmd-3-143-2010, 2010.

Bailey, D., Holland, M., Hunke, E., Lipscomb, B., Briegleb, B., Bitz, C., and Schramm, J.: Community Ice CodE (CICE) User's Guide Version 4.0, available at: http://www.cesm.ucar. edu/models/cesm1.0/cice/doc/index.html, 2010.

Berger, A.: Long Term Variations of Daily Insolation and Quaternary Climatic Changes, J. Atmos. Sci., 35, 2362-2367, 1978.

Bitz, C. M. and Lipscomb, W. H.: An energy-conserving thermodynamic sea ice model for climate study, J. Geophys. Res.-Oceans, 104, 15669-15677, 1999.

Bleck, R. and Smith, L. T.: A Wind-Driven Isopycnic Coordinate Model of the North and Equatorial Atlantic Ocean, 1, Model Development and Supporting Experiments, J. Geophys. Res., 95, 3273-3285, 1990.

Bleck, R., Rooth, C., Hu, D., and Smith, L. T.: Salinity-driven Thermocline Transients in a Wind- and Thermohaline-forced Isopycnic Coordinate Model of the North Atlantic, J. Phys. Oceanogr., 22, 1486-1505, 1992. 
Chandler, M., Rind, D., and Thompson, R.: Joint investigations of the middle Pliocene climate II: GISS GCM Northern Hemisphere results, Global Planet. Change, 9, 197-219, 1994.

Dee, D. P., Uppala, S. M., Simmons, A. J., Berrisford, P., Poli, P., Kobayashi, S., Andrae, U., Balmaseda, M. A, Balsamo, G., Bauer, P., Bechtold, P., Beljaars, A. C. M., van de Berg, L., Bidlot, J., Bormann, N., Delsol, C., Dragani, R., Fuentes, M., Geer, A. J., Haimberger, L., Healy, S. B., Hersbach, H., Hólm, E. V., Isaksen, L., Kållberg, P., Köhler, M., Matricardi, M., McNally, A. P., Monge-Sanz, B. M., Morcrette, J. J., Park, B. K., Peubey, C., de Rosnay, P., Tavolato, C., Thépaut, J. N., and Vitart, F.: The ERA-Interim reanalysis: configuration and performance of the data assimilation system, Q. J. Roy. Meteor. Soc., 137, 553597, doi:10.1002/qj.828, 2011.

Dowsett, H. J., Cronin, T. M., Poore, R. Z., Thompson, R. S., Whatley, R. C., and Wood, A. M.: Micropaleontological evidence for increased meridional heat transport in the North Atlantic Ocean during the Pliocene, Science, 258, 1133-1135, 1992.

Dowsett, H. J., Thompson, R., Barron, J., Cronin, T., Fleming, F., Ishman, S., Poore, R., Willard, D., and Holtz, T.: Joint Investigations of the Middle Pliocene Climate I: PRISM Paleoenvironmental Reconstructions, Global Planet. Change, 9, 169-195, 1994.

Dowsett, H. J., Barron, J., and Poore, R.: Middle Pliocene sea surface temperatures: a global reconstruction, Mar. Micropaleontol., 27, 13-25, 1996.

Dowsett, H. J., Barron, J. A., Poore, R. Z., Thompson, R. S., Cronin, T. M., Ishman, S. E., and Willard, D. A.: Middle Pliocene paleoenvironmental reconstruction: PRISM2, US Geol. Surv., Open File Rep., 99-535, 1999.

Dowsett, H. J., Robinson, M. M., and Foley, K. M.: Pliocene threedimensional global ocean temperature reconstruction, Clim. Past, 5, 769-783, doi:10.5194/cp-5-769-2009, 2009.

Dowsett, H. J., Robinson, M. M., Haywood, A. M., Salzmann, U., Hill, D., Sohl, L., Chandler, M., Williams, M., Foley, K., and Stoll, D.: The PRISM3D paleoenvironmental reconstruction, Stratigraphy 7, 123-139, 2010.

Dukowicz, J. K. and Baumgardner, J. R.: Incremental remapping as a transport/advection algorithm, J. Comput. Phys., 160, 318-335, 2000 .

Eaton, B.: User's Guide to the Community Atmosphere Model CAM-4.0, available at: http://www.cesm.ucar.edu/models/ ccsm4.0/cam/docs/users_guide/ug.html, 2010.

Flato, G. M. and Hibler, W. D.: Ridging and strength in modeling the thickness distribution of Arctic sea ice, J. Geophys. Res.Oceans, 100, 18611-18626, 1995.

Hack, J. J., Boville, B. A., Briegleb, B. P., Kiehl, J. T., Rasch, P. J., and Williamson, D. L.: Description of the NCAR Community Climate Model (CCM2), Technical Report NCAR/TN382+STR, National Center for Atmospheric Research, 120 pp., 1993.

Hansen, J., Ruedy, R., Sato, M., and Lo, K.: Global surface temperature change, Rev. Geophys., 48, RG4004, doi:10.1029/2010RG000345, 2010.

Haywood, A. M. and Valdes, P. J.: Modelling Pliocene warmth: contribution of atmosphere, oceans and cryosphere, Earth Planet. Sci. Lett., 218, 363-377, 2004.

Haywood, A. M., Valdes, P. J., and Sellwood, B. W.: Global scale palaeoclimate reconstruction of the middle Pliocene climate us- ing the UKMO GCM: initial results, Global Planet. Change, 25, 239-256, 2000.

Haywood, A. M., Dowsett, H. J., Otto-Bliesner, B., Chandler, M. A., Dolan, A. M., Hill, D. J., Lunt, D. J., Robinson, M. M., Rosenbloom, N., Salzmann, U., and Sohl, L. E.: Pliocene Model Intercomparison Project (PlioMIP): experimental design and boundary conditions (Experiment 1), Geosci. Model Dev., 3, 227-242, doi:10.5194/gmd-3-227-2010, 2010.

Haywood, A. M., Dowsett, H. J., Robinson, M. M., Stoll, D. K., Dolan, A. M., Lunt, D. J., Otto-Bliesner, B., and Chandler, M. A.: Pliocene Model Intercomparison Project (PlioMIP): experimental design and boundary conditions (Experiment 2), Geosci. Model Dev., 4, 571-577, doi:10.5194/gmd-4-571-2011, 2011.

Hibler, W. D.: Modeling a variable thickness sea ice cover, Mon. Weather Rev., 108, 1943-1973, 1980.

Hill, D. J., Haywood, A. M., Hindmarsh, R. C. A., and Valdes, P. J.: Characterising ice sheets during the mid Pliocene: evidence from data and models, in: Deep time perspectives on climate change: Marrying the signal from computer models and biological proxies, edited by: Williams, M., Haywood, A. M., Gregory, F. J., and Schmidt, D. N., the Micropalaeontological Society, Special Publications, the Geological Society, London, 517-538, 2007.

Hodell, D. A. and Venz-Curtis, K. A.: Late Neogene history of deepwater ventilation in the southern ocean, Geochem. Geophys. Geosyst., 7, Q09001, doi:10.1029/2005GC001211, 2006.

Holtslag, A. A. M. and Boville, B. A.: Local versus nonlocal boundary-layer diffusion in a global climate model, J. Climate, 6, 1825-1842, 1993.

Hunke, E. C. and Dukowicz, J. K.: An elastic-viscous-plastic model for sea ice dynamics, J. Phys.Oceanogr., 27, 1849-1867, 1997.

Hunke, E. C. and Lipscomb, W. H.: CICE: the Los Alamos Sea Ice Model Documentation and Software User's Manual Version 4.1. LA-CC-06-012, available at: http://oceans11.lanl.gov/trac/ CICE, 2010.

Jansen, E., Overpeck, J., Briffa, K. R., Duplessy, J.-C., Joos, F., Masson-Delmotte, V., Olago, D., Otto-Bliesner, B., Peltier, W. R., Rahmstorf, S., Ramesh, R., Raynaud, D., Rind, D., Solomina, O., Villalba, R., and Zhang, D.: Palaeoclimate, in: Climate Change 2007: The Physical Science Basis. Contribution of Working Group I to the Fourth Assessment Report of the Intergovernmental Panel on Climate Change, edited by: Solomon, S., Qin, D., Manning, M., Chen, Z., Marquis, M., Averyt, K. B., Tignor, M., and Miller, H. L., Cambridge University Press, Cambridge, United Kingdom and New York, NY, USA, 2007.

Jiang, D., Wang, H., Ding, Z., Lang, X., and Drange, H.: Modeling the middle Pliocene climate with a global atmospheric general circulation model, J. Geophys. Res., 110, D14107, doi:10.1029/2004JD005639, 2005.

Kiehl, J. T., Hack, J. J., Bonan, G. B., Boville, B. B., Williamson, D. L., and Rasch, P. J.: The National Center for Atmospheric Research Community Climate Model: CCM3, J. Climate, 11, 1131-1149, 1998.

Kluzek, E.: CESM Research Tools: CLM4 in CESM1.0.3 user's guide documentation, available at: http://www.cesm.ucar.edu/ models/cesm1.0/clm/models/lnd/clm/doc/UsersGuide/book1. html, 2011.

Levitus, S. and Boyer, T. P.: World Ocean Atlas Volume 4: Temperature, NOAA Atlas NESDIS 4, US Government Printing Office, Washington, DC, 117, 1994. 
Lipscomb, W. H.: Remapping the thickness distribution in sea ice models, J. Geophys. Res.-Oceans, 106, 13989-14000, 2001.

Lipscomb, W. H. and Hunke E. C.: Modeling sea ice transport using incremental remapping, Mon. Weather Rev., 132, 1341-1354, 2004.

Lipscomb, W. H., Hunke, E. C., Maslowski, W., and Jakacki, J.: Improving ridging schemes for highresolution sea ice models. J. Geophys. Res.-Oceans, 112, C03S91, doi:10.1029/2005JC003355, 2007.

Lunt, D. J., Haywood, A. M., Foster, G., and Stone, E. J.: The Arctic cryosphere in the mid-pliocene and the future, Phil. Trans. R. Soc. A, 367, 49-67, 2009.

Meehl, G. A., Stocker, T. F., Collins, W. D., Friedlingstein, P., Gaye, A. T., Gregory, J. M., Kitoh, A., Knutti, R., Murphy, J. M., Noda, A., Raper, S. C. B., Watterson, I. G., Weaver, A. J., and Zhao, Z. C.: Global climate projections, in: Climate Change 2007: The Physical Science Basis, Contribution of Working Group I to the Fourth Assessment Report of the Intergovernmental Panel on Climate Change, edited by: Solomon, S., Qin, D., Manning, M., Chen, Z., Marquis, M., Averyt, K. B., Tignor, M., and Miller, H. L., Cambridge University Press, Cambridge, United Kingdom and New York, NY, USA, 770-772, 2007.

Neale, R. B., Richter, J. H., Conley, A. J., Park, S., Lauritzen, P. H., Gettelman, A., Williamson, D. L., Rasch, P. J., Vavrus, S. J., Taylor, M. A., Collins, W. D., Zhang, M., and Lin, S.: Description of the NCAR Community Atmosphere Model (CAM 4.0), NCAR technical note, NCAR/TN-485+STR, 2010.

Oleson, K. W., Lawrence, D. M., Bonan, G. B., Flanner, M. G., Kluzek, E., Lawrence, P. J., Levis, S., Swenson S. C., Thornton, P., Dai, A., Decker, M., Dickinson, R., Feddema, J., Heald, C. L., Hoffman, F., Lamarque, J., Mahowald, N., Niu, G., Qian, T., Randerson, J., Running, S., Sakaguchi, K., Slater, A., Stöckli, R., Wang, A., Yang, Z., Zeng, X., and Zeng, X.: Technical Description of version 4.0 of the Community Land Model (CLM), NCAR technical note, NCAR/TN-478+STR, 2010.

Rasch, P. J. and Kristjánsson, J. E.: A comparison of the CCM3 model climate using diagnosed and predicted condensate parameterizations, J. Climate, 11, 1587-1614, 1998.

Ravelo, A. V. and Andreasen, D. H.: Enhanced circulation during a warm period, Geophys. Res. Lett., 27, 1001-1004, 2000.

Raymo, M. E., Grant, B., Horowitz, M., and Rau, G. H.: MidPliocene warmth: stronger greenhouse and stronger conveyor, Mar. Micropaleontol., 27, 313-326, 1996.

Raymond, D. J. and Blyth, A. M.: A stochastic mixing model for non-precipitating cumulus clouds, J. Atmos. Sci., 43, 27082718, 1986.

Raymond, D. J. and Blyth, A. M.: Extension of the stochastic mixing model to cumulonimbus clouds, J. Atmos. Sci., 49, 19681983, 1992.
Richter, J. H. and Rasch, P. J., Effects of convective momentum transport on the atmospheric circulation in the community atmosphere model, version 3, J. Climate, 21, 1487-1499, 2008.

Rosenbloom, N.: Biome4 conversion to LSM, available at: https://wiki.ucar.edu/display/paleo/Biome4+conversion+to+ LSM, 2009.

Rosenbloom, N., Shields, C., Brady, E., Yeager, S., and Levis, S.: CCSM3 for Paleoclimate Applications, 2010.

Rothrock, D. A.: The energetics of the plastic deformation of pack ice by ridging, J. Geophys. Res., 80, 4514-4519, 1975.

Salzmann, U., Haywood, A. M., Lunt, D. J., Valdes, P. J., and Hill, D. J.: A new global biome reconstruction and data-model comparison for the Middle Pliocene, Global Eco. Biogeogr., 17, 432447, 2008.

Seland, Ø., Iversen, T., Kirkevåg, A., and Storelvmo, T.: Aerosolclimate interactions in the CAM-Oslo atmospheric GCM and investigation of associated basic shortcomings, Tellus, 60A, 459491, 2008.

Simmons, A. J. and Strüfing R.: An energy and angular-momentum conserving finite-difference scheme, hybrid coordinates and medium-range weather prediction, Technical Report ECMWF Report No. 28, European Centre for Medium-Range Weather Forecasts, Reading, UK, 68 pp., 1981.

Slingo, J. M.: The development and verification of a cloud prediction scheme for the ECMWF model, Q. J. R. Meteorol. Soc., 113, 899-927, 1987.

Sloan, L. C., Crowley, T. J., and Pollard, D.: Modeling of middle Pliocene climate with the NCAR GENESIS general circulation model, Mar. Micropaleontol., 27, 51-61, 1996.

Sohl, L. E., Chandler, M. A., Schmunk, R. B., Mankoff, K., Jonas, J. A., Foley, K. M., and Dowsett, H. J.: PRISM3/GISS topographic reconstruction, US Geol. Surv. Data Series 419, 6 pp., 2009.

Thorndike, A. S., Rothrock, D. A., Maykut, G. A., and Colony, R.: The thickness distribution of sea ice, J. Geophys. Res., 80, 45014513, 1975.

Vertenstein, M., Craig, T., Middleton, A., Feddema, D., and Fischer, C.: CESM1.0.3 User's Guide, available at: http://www.cesm. ucar.edu/models/cesm1.0/cesm/cesm_doc/book1.html, 2010.

Yan, Q., Zhang, Z., Wang, H., Jiang, D., and Zheng, W.: Simulation of sea surface temperature changes in the Middle Pliocene warm period and comparison with reconstructions, Chinese Sci. Bull., 56, 890-899, 2011.

Zeng, X., Zhao, M., and Dickinson, R. E.: Intercomparison of bulk aerodynamic algorithms for the computation of sea surface fluxes using the TOGA COARE and TAO data, J. Climate, 11, 26282644, 1998.

Zhang, G. J. and McFarlane, N. A.: Sensitivity of climate simulations to the parameterization of cumulus convection in the Canadian Climate Centre general circulation model, Atmos.-Ocean, 33, 407-446, 1995. 